\title{
PENGARUH KEPEMIMPINAN TRANSFORMASIONAL DAN DISIPLIN KERJA TERHADAP KINERJA PEGAWAI DINAS PEMADAM KEBAKARAN DAN PENYELAMATAN KABUPATEN BADUNG
}

\author{
I Made Sumardika ${ }^{1}$ \\ I Made Adi Suwandana ${ }^{2}$ \\ ${ }^{1,2}$ Fakultas Ekonomi Universitas Ngurah Rai, Bali, Indonesia \\ ${ }^{1}$ e-mail : dbuk.prass11@gmail.com
}

\begin{abstract}
ABSTRAK
Penelitian ini bertujuan untuk mengetahui pengaruh secara simultan maupun parsial antara kepemimpinan transformasional dan disiplin kerja terhadap kinerja pegawai Dinas Pemadam Kebakaran dan Penyelamatan Kabupaten Badung. Jumlah sampel ditentukan dengan metode sensus sebanyak 50 orang pegawai Dinas Pemadam Kebakaran dan Penyelamatan Kabupaten Badung. Data dianalisis dengan menggunakan uji asumsi klasik, analisis regresi linier berganda, analisis korelasi berganda, analisis determinasi, uji signifikansi simultan (F-test) dan uji signifikansi parsial (t-test). Hasil penelitian menunjukkan ada pengaruh yang positif dan signifikan secara simultan maupun parsial antara kepemimpinan transformasional dan disiplin kerja terhadap kinerja pegawai Dinas Pemadam Kebakaran dan Penyelamatan Kabupaten Badung.
\end{abstract}

Kata kunci : Kepemimpinan Transformasional, Disiplin Kerja, Kinerja Pegawai

\begin{abstract}
This study aims to determine the effect simultaneously or partially between transformational leadership have a positive impact and signifcantly to the employee performance in departement fire brigade and rescue Badung regency. The number of samples was determined by the census method as many as 50 production employees of departement fire brigade and rescue Badung regency.. Data were analyzed using classic assumption test, multiple linear regression analysis, multiple correlation analysis, analysis of determination, simultaneous significance test $(F$-test) and partial significance test ( $t$-test). The results showed that there were simultaneous and partial positive and significant effects of transformational leadership have a positive impact and signifcantly to the employee performance in departement fire brigade and rescue Badung regency.
\end{abstract}

Keywords: Tranformational Leadership, work disciplin, performance employee 


\section{PENDAHULUAN}

Gaya kepemimpinan mrupakan atau prilaku kepemimpinan seseorang pemimpin dalam hubungannya dengan bawahan. Salah satu gaya kepemimpinan yang sesuai dalam menghadapi perubahan adalah gaya kepemimpinan transformasional. Michael (2006) menyatakan, gaya kepemimpinan transformasional adalah suatu metode kepemimpinan yang memotivasi para pengikutnya untuk bekerja mencapai sebuah tujuan, bukan untuk kepentingan pribadi jangka pendek, dan untuk mencapai prestasi dan aktualisasi diri.

Sumber daya manusia sebagai seorang yang siap, mau dan mampu memberi sumbangan usaha pencapaian tujuan organisasi (Rivai, 2003:6). Michael (2006) menyatakan, gaya kepemimpinan transformasional adalah suatu metode kepemimpinan yang memotivasi para pengikutnya untuk bekerja mencapai sebuah tujuan, bukan untuk kepentingan pribadi jangka pendek, dan untuk mencapai prestasi dan aktualisasi diri.

Dinas Pemadam Kebakaran dan Penyelamatan Kabupaten Badung merupakan salah satu Organisasi Perangkat Daerah (OPD) yang bergerak dalam bidang penanggulangan bencana khususnya kebakaran berfokus pada pengembangan Sumber Daya Manusia yang berkualitas. Namun demikian, dalam upaya menciptakan kinerja pegawai Dinas Pemadam Kebakaran dan Penyelamatan Kabupaten Badung, nampaknya masih terdapat banyak kendala yang dihadapi sehingga sulit untuk mencapai tujuan organisasi. Kondisi yang belum ideal masih ada di Dinas Pemadam Kebakaran dan Penyelamatan Kabupaten Badung. Di mana masih ada kendala di Dinas
Pemadam Kebakaran dan Penyelamatan Kabupaten Badung antara lain pegawai yang masih kurang disiplin serta efektivitas kepemimpinan yang masih relatif rendah sehingga masih terjadi adanya keluhan terhadap kinerja pegawai serta disiplin kerja yang dirasakan masih kurang, sehingga mengakibatkan kinerja pegawai masih kurang maksimal.

Adapun tujuan dalampenelitian ini untuk mengetahui pengaruh kepemimpinan transformasional dan disiplin kerja secara parsial terhadap kinerja pegawai Dinas Pemadam Kebakaran dan Penyelamatan Kabupaten Badung. untuk mengetahui pengaruh kepemimpinan transformasional dan disiplin kerja secara simultan terhadap kinerja pegawai Dinas Pemadam Kebakaran dan Penyelamatan Kabupaten Badung.

\section{METODE PENELITIAN}

Jenis penelitian ini adalah penelitian asosiatif kausal dengan menggunakan pendekatan kuantitatif. Penelitian asosiatif kausal adalah penelitian yang bertujuan untuk mengetahui pengaruh antara dua variabel atau lebih (Umar, 2005:189). Penelitian ini menjelaskan hubungan memengaruhi dan dipengaruhi dari variabel-variabel yang akan diteliti. Adapun pendekatan yang digunakan pada penelitian ini adalah pendekatan kuantitatif karena data yang akan digunakan untuk menganalisis hubungan antar variabel dinyatakan dengan angka atau skala numerik (Kuncoro, 2007:23). Penelitian ini menganalisis hubungan antara kepemimpinan transformasional dan disiplin kerja terhadap kinerja karyawan.

Jumlah populasi dalam penelitian ini adalah 50 orang pegawai. Sampel 
penelitian ini ditentukan yaitu sebanyak 50 orang pegawai, dengan menggunakan metode sensus dimana semua anggota populasi digunakan sebagai sampel. Hal ini sering dilakukan bila jumlah populasi relative kecil, kurang dari 100 orang Arikunto (2006:112). Teknik pengumpulan data dalam penelitian ini dilakukan dengan observasi, wawancara, studi dokumentasi dan kuesioner. Setiap jawaban kuesioner mempunyai bobot atau skor nilai dengan skala Likert sebagai berikut : STS (sangat tidak setuju $)=$ skor 1, TS $($ tidak setuju $)=$ skor 2, N (netral) = skor 3, S (setuju) $=$ skor 4 dan $\mathrm{SS}($ sangat setuju $)=$ skor 5 .
Teknik analisis data dalam penelitian ini menggunakan pendekatan kuantitatif yaitu analisis statistik inferensial, terdiri dari: uji asumsi klasik, analisis regresi linier berganda, analisis determinasi, uji signifikansi parsial (t-test) dan uji signifikansi simultan (Ftest).

\section{HASIL DAN PEMBAHASAN Uji Asumsi Klasik}

Uji asumsi klasik digunakan untuk mengetahui kelayakan penggunaan modelregresi. Hasil uji multikolinearitas dapat dilihat pada Tabel 1 .

\section{Tabel 1}

Hasil Uji Multikolinearitas

\begin{tabular}{|c|c|c|}
\hline $\begin{array}{ll}\text { Dimensi } & \text { Variabel } \\
\text { Bebas } & \end{array}$ & $V I F$ & Tolerance \\
\hline $\begin{array}{l}\text { Kepemimpinan } \\
\text { Trasformasional } \\
\text { Disiplin Kerja }\end{array}$ & 1,662 & 0,602 \\
\hline
\end{tabular}

Dari Tabel 1 di atas terlihat bahwa semua variabel bebas mempunyai koefisien VIF lebih kecil dari 10 dan toleransi lebih besar dari 0,10. Dengan demikian dapat disimpulkan bahwa semua variabel bebas dalam penelitian adalah bebas dari Gejala Multikolinieritas.

Hasil uji heteroskedastisitas dapat dilihat pada Tabel 2.

Tabel 2

Hasil Uji Heteroskedastisitas dengan Uji Glejser

\begin{tabular}{|l|l|l|}
\hline Model & $\mathrm{t}$ & Sig. \\
\hline constan & 1.373 & .176 \\
Kepemimpinan & 3.012 & .004 \\
Trasformasional & & \\
Disiplin Kerja & 3.109 & .003 \\
\hline
\end{tabular}

a. Dependent Variable: kinerja_karyawan

Sumber: Olah data SPSS 18.0 for Windows, 2019 
Hasil ini menunjukkan bahwa koefisien regresi nilai absolut residual tidak signifikan, sehingga tidak terjadi heteroskedastisitas pada variabel keselamatan kerja dan kesehatan kerja.

Hasil uji normalitas dapat dilihat pada Tabel 3.

Tabel 3

Hasil Uji Uji Normalitas dengan Uji Kolmogorov-Smirnov

\begin{tabular}{|l|l|}
\hline & $\begin{array}{l}\text { Unstandardized } \\
\text { Residual }\end{array}$ \\
\hline $\mathrm{N}$ & 50 \\
Kolmogorov-Smirnof $Z$ & .108 \\
Asymp. Sig (2-tailed) & .200 \\
\hline \multicolumn{2}{|l|}{ Sumber: Olah data SPSS 18.0 for Windows, 2019 }
\end{tabular}

Dari Tabel 3 di atas dapat dilihat bahwa asymp. Sig (2-taileg) residual adalah 0,200 lebih besar dari 0,05 dengan demikian dapat dikatakan variabel tersebut adalah berdistribusi normal.

Hasil analisis regresi linier berganda dapat dilihat pada Tabel 4

Tabel 4

Hasil Analisis Regresi Linier Berganda

\begin{tabular}{|l|l|l|}
\hline \multirow{2}{*}{ Model } & \multicolumn{2}{|l|}{$\begin{array}{l}\text { Unstandardized } \\
\text { Coefficients }\end{array}$} \\
\cline { 2 - 3 } & $\mathrm{B}$ & Std.Error \\
\hline 1. (constant) & 2,337 & 1,702 \\
X1 & 0,488 & 0,162 \\
X2 & 0,355 & 0,114 \\
\hline \multicolumn{2}{|l}{} \\
\hline
\end{tabular}

Sumber: Olah data SPSS 18.0 for Windows, 2019

Berdasarkan nilai a, $\mathrm{b}_{1}$, dan b2 pada Tabel 4 di atas diperoleh persamaan garis regresi linier $\mathrm{Y}=2,337+0,488 \mathrm{X}_{1}+$ $0,355 \mathrm{X}_{2}$ persamaan ini memberikan informasi bahwa:

$\mathrm{a}=2,337$, artinya apabila variabel kepemimpinan tranformasional $\left(\mathrm{X}_{1}\right)$ dan variabel disiplin kerja $\left(\mathrm{X}_{2}\right)$ sama dengan nol (0) maka besarnya Kinerja karyawan adalah sebesar 2,337.

$\mathrm{b}_{1}=0,488$, artinya apabila disiplin kerja $\left(\mathrm{X}_{2}\right)$ dianggap konstan maka meningkatnya kepemimpinan kerja $\left(\mathrm{X}_{1}\right)$ sebesar satu satuan akan diikuti oleh meningkatnya Kinerja pegawai (Y) sebesar 0,488.

$\mathrm{b}_{2}=0,355$, artinya apabila kepemimpinan transformasional $\left(\mathrm{X}_{1}\right)$ dianggap konstan maka meningkatnya disiplin kerja $\left(\mathrm{X}_{2}\right)$ sebesar satu satuan akan diikuti oleh meningkatnya Kinerja pegawai (Y) sebesar 0,355 .

Dengan demikian dapat dinyatakan Kinerja pegawai dipengaruhi secara serempak oleh kepemimpinan transformasional dan disiplin kerja. 
Hasil analisis determinasi dapat dilihat pada Tabel 5 .

Tabel 5

Hasil Analisis Determinasi

\begin{tabular}{|l|l|l|}
\hline Model & $\mathrm{R}$ & Rsquare \\
\hline 1 & 0.721 & 0.519 \\
\hline \multicolumn{2}{|l|}{ Sumber: Olah data SPSS 18.0 for Windows, 2019}
\end{tabular}

Tabel 5 dapat dilihat bahwa $\mathrm{R}=$ 0,519, maka koefisien determinasi $51,9 \%$ berarti besarnya variasi pengaruh antara variabel kepemimpinan transformasional dan disiplin kerja terhadap Kinerja pegawai adalah 51,9\% sedangkan sisanya $48,1 \%$ ditentukan oleh variabel lain dari transformasional dan disiplin kerja yang tidak dibahas dalam penelitian ini.

Hasil analisis Uji f-test dapat dilihat pada Tabel 6.

Tabel 6

Hasil Analisis Uji f-test

\begin{tabular}{|l|l|l|l|}
\hline \multicolumn{2}{|l|}{ Model } & F & Sig. \\
\hline 1 & $\begin{array}{l}\text { Regression } \\
\text { Residual } \\
\text { Total }\end{array}$ & 25.388 & $.000^{\mathrm{b}}$ \\
\hline
\end{tabular}

Dari Tabel 6 diperoleh signifikansi F sebesar $0,00<0,05$ dan $F_{\text {hitung }} 25,388>$ $\mathrm{F}_{\text {tabel }}$ 3,195. Menunjukkan bahwa dengan uji statistik kepemimpinan transformasional dan disiplin kerja berpengaruh nyata (signifikan) terhadap kinerja pegawai. Ini berarti hipotesis pertama yang berbunyi "kepemimpinan transformasional dan disiplin kerja berpengaruh positif dan signifikan terhadap kinerja pegawai Dinas Pemadam Kebakaran dan Penyelamatan Kabupaten Badung " dapat diterima

Hasil analisis Uji t-test dapat dilihat pada Tabel 7.

Tabel 7

Hasil Analisis Uji t-test

\begin{tabular}{|l|r|r|r|}
\hline \multicolumn{2}{|l|}{ Model } & \multicolumn{1}{c|}{$\mathrm{t}$} & \multicolumn{1}{c|}{ Sig. } \\
\hline 1 & (Constant) & 1.373 & .176 \\
& kepemimpinan_transfor & 3.012 & .004 \\
& masiona & & \\
& disiplin_kerja & 3.109 & .003 \\
\hline
\end{tabular}


Dari Tabel 7 terlihat bahwa thitung $3,012>t_{\text {tabel }}$ 1,684. Ini berarti bahwa secara statistik Kepemimpinan transformasional berpengaruh nyata terhadap kinerja pegawai Dinas Pemadam Kebakaran dan Penyelamatan Kabupaten Badung. Berarti hipotesis yang menyatakan" Variabel kepemimpinan transformasional berpengaruh positif dan signifikan terhadap kinerja pegawai pada Dinas Pemadam Kebakaran dan Penyelamatan Kabupaten Badung" dapat diterima. Serta untuk disiplin kerja terhadap kinerja karyawan terlihat bahwa thitung $3,109>t_{\text {tabel }} 1,684$. Ini berarti bahwa secara statistik disiplin kerja berpengaruh nyata terhadap kinerja pegawai Dinas Pemadam Kebakaran dan Penyelamatan Kabupaten Badung. Berarti hipotesis yang menyebutkan "Variabel disiplin kerja berpengaruh positif dan signifikan terhadap kinerja pegawai pada Dinas Pemadam Kebakaran dan Penyelamatan Kabupaten Badung " dapat diterima.

\section{PENUTUP}

\section{KESIMPULAN}

Berdasarkan hasil analisis data dan pembahasan, maka didapat kesimpulan hasil penelitian pada Dinas Pemadam Kebakaran dan Penyelamatan Kabupaten Badung. Ada pengaruh yang positif secara simultan antara kepemimpinan transformasional dan disiplin kerja terhadap kinerja pegawai. Ada pengaruh yang positif dan signifikan antara kepemimpinan transformasional terhadap kinerja pegawai serta Ada pengaruh yang positif dan signifikan antara disiplin kerja dengan kinerja pegawai Dinas Pemadam
Kebakaran dan Penyelamatan Kabupaten Badung.

\section{SARAN-SARAN}

Berdasarkan hasil analisis data dan pembahasan, maka didapat kesimpulan hasil penelitian pada Dinas Pemadam Kebakaran dan Penyelamatan Kabupaten Badung. Ada pengaruh yang positif secara simultan antara kepemimpinan transformasional dan disiplin kerja terhadap kinerja pegawai. Ada pengaruh yang positif dan signifikan antara kepemimpinan transformasional terhadap kinerja pegawai serta Ada pengaruh yang positif dan signifikan antara disiplin kerja dengan kinerja pegawai Dinas Pemadam Kebakaran dan Penyelamatan Kabupaten Badung.

Kinerja pegawai di lingkungan Dinas Pemadam Kebakaran dan Penyelamatan Kabupaten Badung dapat ditingkatkan dengan cara pemimpin selalu memberikan bawahan untuk ikut serta memberikan ide, gagasan serta menerima masukan dari bawahan. Disiplin kerja dapat di tingkatkan dengan cara atasan maupun bawahan agar menaati aturan yang berlaku, pemimpin perlu melakukan apel setiap harinya untuk memantau pegawai yang hadir dan peawai maupun tasan siap menerima konsekuensi jika melakukan pelanggaran sehingga tujuan organisasi tercapai dengan baik, kepemimpinan transformasional dan disiplin kerja tidak hanya yang mempengaruhi kinerja pegawai namun ada variable-variabel lain yang mempengaruhi kinerja pegawai yaitu : pendidikan, pengalaman kerja, lingkungan kerja dan motivasi, 
Pengaruh Kepemimpinan Transformasional dan Disiplin Kerja Terhadap Kinerja Pegawai Dinas Pemadam Kebakaran dan Penyelamatan Kabupaten Badung

maka untuk penelitian selanjutnya dapat menanmbahkan dengan variabelvariabel lain tersebut.

DAFTAR PUSTAKA

Arikunto, S. 2006. Metode Penelitian Kualitatif. Jakarta: Bumi Aksara

Husein Umar, 2005. Metode Penelitian. Jakarta : Salemba Empat

Kuncoro, Mudrajad. Ekonomika Industri Indonesia Menuju Negara Industri Baru 2030 (Edisi I). Yogyakarta: ANDI, 2007.

Michael. Amstrong, (2006). Manajemen Sumber Daya Manusia. PT Elexmedia Komputindo, Jakarta

Husein Umar, 2005. Metode Penelitian. Jakarta : Salemba Empat

Rivai, V. (2003). Manajemen Sumber Daya Manusia Untuk Perusahaan: Jakarta. 